\title{
Broiler Breeder Performance in The Final Phase of Grower
}

\author{
Tetty Barunawati Siagian a, Nabilah Khoirunnisa Nugraheni ${ }^{b}$ \\ $a, b$ School of Vocational Studies, IPB University, Bogor, West Java, Indonesia \\ email:aTettybarunawatisiagian@apps.ipb.ac.id,bNabilah_pvt@apps.ipb.ac.id
}

\begin{tabular}{l}
\hline A R T I C L E I N F O \\
\hline Article history: \\
Received 04 July 2021 \\
Revised 11 October 2021 \\
Accepted 03 December 2021 \\
Available online 30 December \\
2021
\end{tabular}

Keywords: Broiler Breeder Bodyweight Gain Feed Consumption Feed Conversion Performance

IEEE style in citing this article:

T.B. Siagian and N.K. Nugraheni, "Broiler Breeder Performance in The Final Phase of Grower," Jurnal Ternak, vol. 12 , no. 2 , pp. $36-40$, 2021.

\begin{abstract}
A B S T R A C T
One of the comestibles that have high nutritional value and are easy to obtain is chicken. The higher demand for chicken must be accompanied by an increase in production. It is important for the breeder of broiler chicken to choose high quality Day Old Chick (DOC) from the broiler breeder which also has high quality and productivity. The type of broiler breeder that is grown in PT. Karya Indah Pertiwi is Ross 308 . Observations were made when the chickens were 18th to 21st weeks old in 6 henneries totaling about 10,000 chickens. The performance of broiler breeder observed were feed consumption, bodyweight gain, feed conversion ratio, and uniformity. Feed consumption of broiler breeder at 18th to 21st week was 659.4 $\mathrm{g} /$ chicken, 700,583 g/chicken, 742,116 g/chicken, 767.2 g/chicken. Bodyweight gain at 18 th to 21 st week was $143.51 \mathrm{~g} /$ chicken, $193.3 \mathrm{~g} /$ chicken, $63.43 \mathrm{~g} /$ chicken, 167.96 $\mathrm{g} /$ chicken. Feed conversion ratio at 18 th to 21 st week was $4.5,3.6,11.6,4.5$. The uniformity at 18 th to 21 st week was $77 \%, 81 \%, 81 \%, 81 \%$. In conclusion, the value of feed consumption for broiler breeder at PT. Karya Indah Pertiwi was increasing every week. Bodyweight gain at 20th week was lower than 18th, 19th, and 21st week. The value of feed conversion ratio at 20th week was higher than at 18 th, $19^{\text {th }}$, and 21 st week. Chicken uniformity value at 18 th week was not good it was at $77 \%$, while at the 19 th, $20^{\text {th }}$, and 21 st week it was quite good at $81 \%$.
\end{abstract}

\section{Introduction}

Along with population growth, the need for comestibles with high nutritional value is correspondingly increasing. One of the comestibles that have high nutritional value and is easy to obtain is chicken. Chicken contains 18.20 grams of protein, 25 grams of fat, and has calories of 404 Kcal per 100 grams of chicken [1]. The higher demand for chicken must be accompanied by an increase in production. Production factors that affect broiler chicken are DOC (Day Old Chick), feed, vitamins, heating and death [2]. The success of raising broilers commercial depends on the quality of the DOC that is kept. DOC that is maintained is of high quality so that during its maintenance it will not experience problems so that the resulting performance depends on environmental factors [3]. It is important for the breeder of broiler chicken to choose high-quality Day Old Chick from broiler breeder which also has highquality and productivity, so that it can help increase the production of broiler chicken. One way that can be done to get high-quality hatching eggs is to control the performance of broiler breeders based on bodyweight gain, feed consumption, feed conversion, and uniformity [4].

\section{Material and Method}

Observations were made when the chickens were 18th to 21st week old in 6 henneries totaling about 10,000 chickens. Data collection includes primary data and secondary data. Primary data is data collected through the first party, usually through interviews, traces, and others [5]. Primary data 
obtained at PT. Karya Indah Pertiwi was from direct participation in feeding, weighing chickens, and raising chickens. Secondary data is data obtained from official documents, books related to the object of research, research results in the form of reports, theses, dissertations, and laws and regulations [6]. Secondary data obtained from records belong to PT. Karya Indah Pertiwi and literature studies.

\section{Results and Discussion}

The result of observations on the performance of broiler breeder at the age of 18th - 21st week at PT. Karya Indah Pertiwi is presented in Table 1.

Table 1 Performance of broiler breeder at the age of 18th - 21st week at PT. Karya Indah Pertiwi

\begin{tabular}{ccccc}
\hline $\begin{array}{c}\text { Performance of } \\
\text { Broiler Breeder }\end{array}$ & 18th & $19^{\text {th }}$ & 20th & 21 st \\
\cline { 2 - 5 } & 659.4 & 700,583 & 742,116 & 767.2 \\
\hline $\begin{array}{c}\text { Feed Consumption } \\
\text { (g/chicken) }\end{array}$ & 143.51 & 193.3 & 63.43 & 167.96 \\
\hline $\begin{array}{c}\text { Bodyweight gain } \\
\text { (g/chicken) }\end{array}$ & 4.5 & 3.6 & 11.6 & 4.5 \\
\hline FCR & $77 \%$ & $81 \%$ & $81 \%$ & $81 \%$ \\
\hline Uniformity (\%) & & & & \\
\hline
\end{tabular}

\subsection{Feed Consumption}

Feed is a very important requirement and must be considered in every livestock business. Feed is given according to the amount and nutritional needs of animals based on age or growth period [7]. Feeding chickens at PT. Karya Indah Pertiwi was only done once per day every morning at around 07.00 WIB. The purpose of this feed is to control the bodyweight of the chickens.

The method of feeding for broiler breeder was not given ad libitum but in a limited way (restricted feeding). Restricted feeding is done with the aim that the broiler breeder that are kept are not overweight. If the weight of the chicken is more than the suggested weight, it can cause a lot of losses, such as decreased productivity, more sensitivity to disease, susceptible to heat stress and higher mortality [7].

The feed used in PT. Karya Indah Pertiwi is Sierad Feed B 302 R. This feed is a complete grain feed made from ingredients such as corn, bran, soybean meal, full-fat soya, CPO (Crude Palm Oil), stone flour, calcium, phosphorus, amino acids, salt, vitamins, minerals, and antioxidants. The nutrient composition of Sierad Feed B 302 R is: a. Max water content 13\%, b. Protein min 15\%, c. Fat min 8\%, d. Fiber max $6 \%$, e. Ash max 8\%, f. Calcium 3-4\%, g. Phosphorus $0.9-1.2 \%$, p. Lysine $\min 0.64 \%$, i. Methionine $\min 0.27 \%$, j. Tryptophan $\min 0.11 \%$, k. meth. + Cys. min $0.52 \%$, l. Aplatoxin total 40 ppb, $\mathrm{m}$. Metabolic energy min $2700 \mathrm{kcal}$. Good feed for Ross 308 breeder chicken in the grower phase, in which every kilogram of it contains the following nutrients : energy of $2800 \mathrm{kcal}$, crude protein $14-15 \%$, Lysine $0.68 \%$, Tryptophan $0.16 \%$, and other contents [8].

Feed consumption of chicken is obtained from the amount of feed given minus the feed refusal. The results for feed consumption of broiler breeder at PT. Karya Indah Pertiwi based on Table 1, when converted into daily consumption, it was $94.2 \mathrm{~g} /$ chicken/day for the 18th week, 100,083 g/chicken/day for the 19th week, 106,016 g/chicken/day for the 20th week, and $109.6 \mathrm{~g} /$ chicken/day for the 21st week. The results for the 18th to 21st week of feed consumption are quite good when compared to the standard 
set by PT. Karya Indah Pertiwi it's 90 g/chicken/day for the 18th week, $96 \mathrm{~g} /$ chicken/day for the 19th week, $101 \mathrm{~g} / \mathrm{chicken/day} \mathrm{for} \mathrm{the} \mathrm{20th} \mathrm{week,} \mathrm{and} 106 \mathrm{~g} / \mathrm{chicken/day} \mathrm{for} \mathrm{the} \mathrm{21st} \mathrm{week.}$

The good results of feed consumption are caused by several factors. The factors that affect feed consumption are the density of the type of feed material, the physical form of the feed, the level of feed palatability, and the energy content of the feed. The feed given is in the form of granules or crumbles, this form affects the consumption of chicken feed [9]. Broilers fed in the form of pellets and crumbles had a higher feed intake than rations in the form of mash. The feed also contains oils and fats that can increase palatability [10]. The use of oil or fat in the preparation of rations for poultry can improve the palatability or taste of the ration [11].

\subsection{Bodyweight Gain}

Bodyweight gain is the increase in body weight achieved by an animal over a certain period. Chicken growth is usually detected by the growth of body weight per day, per week, or per other units of time [12].

The results of bodyweight gain were obtained at PT. Karya Indah Pertiwi, in the 18th week, 19th week, and 21st week showed that the bodyweight gain of broiler breeder was quite high compared to the Ross 308 breeder performance guide from Aviagen 2021 [13], which was 140 g/chicken/week for chicken on 18th week, $140 \mathrm{~g} /$ chicken/week for chicken on 19th week, and $160 \mathrm{~g} / \mathrm{chicken} /$ week for chicken on 21st week. The bodyweight gain obtained at week 20 was lower than the Ross 308 breeder performance guide from Aviagen 2021 which was $160 \mathrm{~g} /$ chicken/week. This can be caused by several factors.

Factors that affect bodyweight gain are differences in gender, feed consumption, environment, seeds, and feed quality [14]. The increase in body weight of broiler breeder chickens at week 20 is not in line with feed consumption at week 20. Feed consumption for broiler breeders in the 20th week increased from the previous week and can be said to be quite good when compared to the feed consumption standards that have been set by PT. Karya Indah Pertiwi. This may occur due to an error during the weighing process. Another factor that may be the reason for the decrease in bodyweight gain of chickens in the 20th week is the change in the environmental conditions, because in the 20th week the nests for laying eggs have begun to be placed in the hennery. The nests are placed at week 20 in preparation for the next egg-laying period, so that the chickens have time to adapt to the nest. Chickens that in the process of adaptation to the new environment will require more energy than usual, so the possibility of decreasing bodyweight gain in the 20th week is caused by this factor.

\subsection{Feed Conversion Ratio (FCR)}

Feed Conversion Ratio is the ratio between feed consumption and bodyweight gain obtained over a certain period of time. FCR is used to measure livestock productivity, the higher the FCR, the more rations are needed to increase body weight [15]. The formula for measuring FCR is feed consumption divided by chicken bodyweight gain.

The results of the conversion of broiler breeder rations at week 20th at PT. Karya Indah Pertiwi was higher than the FCR in the 18th, 19th, and 21st. FCR is obtained by dividing feed consumption by bodyweight gain in the same unit of time. In the Aviagen 2021 guide, it can be calculated manually to find the FCR of broiler breeders. The FCR guidance for week 18 is 4.45 , for week 19 it is 4.65 , for week 20 it is 4.95 and for week 21 it is 4.59 . The feed conversion ratio value that was too high was probably due to the fact that the amount of ration consumed was not entirely for production, but rather used for other purposes; to adjust body temperature to the ambient temperature. The factors that influence the FCR are genetics, temperature, ventilation, sanitation, feed quality, type of ration, use of additives, water quality, disease, and maintenance management [16].

The factors causing the high value of feed conversion ratio are excessive feeding, where the feed does not meet the standards. Thus, a lot of feed is scattered, chickens are attacked by diseases, especially 
respiratory tract diseases resulting in appetite decreases, the ammonia gas content in the cage is high, the temperature in the cage is high, and the quality of feed is not good [17].

\subsection{Uniformity}

Uniformity is determined from the percentage of body weight is within the limit of $10 \%$ [18] or $15 \%$ [19] above and below the average weight of the population. The uniformity value of chickens is obtained by dividing the number of chickens that fall into the $10 \%$ limit above or below the average bodyweight by a large number of chicken samples.

The result for uniformity of broiler breeder at PT. Karya Indah Pertiwi showed that the uniformity value of chickens at week 18th was lower than the standard of uniformity value for good chickens, which is $80 \%$. Flock of chicken is said to be uniform if it shows a uniformity value of $80 \%$ [20]. The uniformity value of chickens at weeks 19th, 20th, and 21st was quite good at $81 \%$. The factors that affect uniformity are the density of the cage, the need for feed and drinking places, temperature and humidity, and the length of lighting [21].

As an example of calculating the uniformity value, for the 21st week, the average body weight of 1,400 chicken samples of PT. Karya Indah Pertiwi is 2,359.7 $\mathrm{g}$ and $235.97 \mathrm{~g}$ for the tolerance value. The tolerance value was obtained from the average body weight of the chicken multiplied by $10 \%$. The upper tolerance limit obtained is 2,595.67 $\mathrm{g}$ and the lower tolerance limit obtained is 2,123.73 $\mathrm{g}$. The upper tolerance limit is obtained from the sum of the average body weight with a tolerance value, while the lower tolerance limit is obtained from the reduction of the average body weight with a tolerance value.

The number of chickens that have bodyweight between the upper and lower tolerance limits is then calculated and entered into the uniformity level formula. The number of samples of broiler breeders with weights between the upper and lower tolerance limits at week 21st was 1,143 chickens.

Uniformity of broiler breeder $=\frac{1.143}{1.400} \times 100 \%$.

The above calculation shows that the level of uniformity of the broiler breeder at week 21st is $81 \%$. The level of uniformity is in a fairly good uniformity, in line with the opinion of [3] that a good level of uniformity of chickens is $80 \%$. A good uniformity of broiler breeder in the grower phase can help in realizing the sexual maturity of chickens simultaneously so that the chickens can be mated simultaneously.

\section{Conclusions}

The value of feed consumption for broiler breeder at PT. Karya Indah Pertiwi was increasing every week. Bodyweight gain in the 20th week was lower than 18th, 19th, and 21st week. The value of feed conversion ratio at 20th week was higher than 18 th, 19 th and $21^{\text {st }}$ week. Chicken uniformity value at 18 th week was not good, it was at $77 \%$, while at the 19th, 20th and 21 st week it was quite good at $81 \%$.

\section{Acknowledgment}

The author would like to say gratitude to the workers from PT. Karya Indah Pertiwi, Panumbangan Sub-District, Ciamis Regency, West Java, Indonesia.

\section{References}

[1] Direktorat Gizi Departemen Kesehatan, Daftar Komposisi Bahan Makanan. Jakarta: Penerbit Bhratara, 2010.

[2] S. Hadi and E. Siti, "Factors Affecting Broiler Production in Wonogiri Regency," Am. Sci. Res. J. Eng. Technol. Sci., vol. 28, no. 1, pp. 1-13, 2017.

[3] R. Fadilah and Fatkhuroji, Memaksimalkan Produksi Ayam Ras Petelur. Jakarta: AgroMedia Pustaka, 2013. 
[4] M. Y.F and Sumiati, "Manajemen perkandangan ayam bibit pedaging strain ross dan lohman di PT. Silga Perkasa Sukabumi Jawa Barat," Bogor, 2010. [Online]. Available: https://www.academia.edu/31801156/Breeding_Farm.

[5] S. Arikunto, Prosedur penelitian: suatu pendekatan praktik. Jakarta: Rineka Cipta, 2010.

[6] Z. Ali, Metode Penelitian Hukum. Jakarta: Sinar Grafika, 2009.

[7] A. J. Marwansyah, I. N. S. Miwada, and A. W. Puger, “Manajemen pemberian pakan ayam broiler parent stock fase layer di pt. Charoen pokphand jaya farm unit 8 probolinggo jawa timur," J. Trop. Anim. Sci., vol. 5, no. 1, pp. 181-188, 2019.

[8] Aviagen, "Ross 308 European Parent stock: Nutrition Specifications," pp. 1-8, 2016, [Online]. Available: http://eu.aviagen.com/assets/Tech_Center/Ross_PS/Ross308-PS-NS-2016-EN.pdf.

[9] R. D. Ariska, "Pengaruh pemberian campuran onggok dan molase terfermentasi terhadap konsumsi pakan, konversi pakan dan pertambahan bobot badan ayam pedaging," Universitas Islam Negeri Maulana Malik Ibrahim, 2012.

[10] A. A. Arifin, M. Purnaningrum, B. Mikuwati, and Aksi, "Kibble Sebagai Strategi Peningkatan Performa dan Karakteristik Karkas Berbasis Habitus Alamiah Ayam Broiler," pp. 1-38, 2015.

[11] I. G. N. G. Bidura, "Bahan Ajar: Bahan Makanan Ternak," pp. 1-133, 2016.

[12] M. Islam, Z. Khandaker, S. Chowdhury, and K. Islam, "Effect of citric acid and acetic acid on the performance of broilers," J. Bangladesh Agric. Univ., vol. 6, no. 2, pp. 315-320, 2008, doi: 10.3329/jbau.v6i2.4828.

[13] Aviagen, "Ross 308 Parent stock: Performance Objectives." pp. 1-12, 2021, [Online]. Available: https://ap.aviagen.com/assets/Tech_Center/Ross_PS/Ross308-ParentStock-

PerformanceObjectives-2021-EN.pdf.

[14] A. Qurniawan, I. I. Arief, and R. Afnan, "Kualitas Daging Dan Performa Ayam Broiler Di Kandang Terbuka Pada Ketinggian Tempat Pemeliharaan Yang Berbeda Di Kabupaten Takalar Sulawesi Selatan," IPB University, 2016.

[15] A. T. Marom, U. Kalsum, and U. Ali, "Evaluasi Performans Broiler pada Sistem Kandang Close House dan open house dengan altitude berbeda," Din. Rekasatwa, vol. 2, no. 2, pp. 1-10, 2017.

[16] A. Idayat, U. Atmomarsono, and W. Sarengat, "Pengaruh Berbagai Frekuensi Pemberian Pakan Pada Pembatasan Pakan Terhadap Performans Ayam Broiler," Anim. Agric. J., vol. 1, no. 1, pp. 379-388, 2012.

[17] H. Subkhie, Suryahadi, and A. Saleh, "Analisis Kelayakan Usaha Peternakan Ayam Pedaging dengan Pola Kemitraan di Kecamatan Ciampea Kabupaten Bogor," Manaj. IKM, vol. 7, no. 1, pp. 54-63, 2012.

[18] S. A. Abbas, A. A. Gasm Elseid, and M. K. A. Ahmed, "Effect of body weight uniformity on the productivity of broiler breeder hens," Int. J. Poult. Sci., vol. 9, no. 3, pp. 225-230, 2010, doi: 10.3923/ijps.2010.225.230.

[19] B. P. Hudson, R. J. Lien, and J. B. Hess, "Effects of Body Weight Uniformity and Pre- Peak Feeding Programs on Broiler Breeder Hen Performance," J. Appl. Poult. Res., vol. 10, no. 1, pp. 24-32, 2001.

[20] Yusri, "Performa Ayam Ras Petelur pada Periode Awal Bertelur Dengan Kombinasi Berat Badan Pre-layer dan Pemberian Jumlah Pakan yang Berbeda," Universitas Hasanuddin, 2015.

[21] Y. Putra, "Tingkat Keseragaman Bobot Badan (Uniformity) Strain Cobb pada Pemeliharaan Periode Starter di PT. Charoen Pokphand Jaya Farm 4 Pekanbaru," Politeknik Pertanian Negeri Payakumbuh, 2015. 